\title{
Constructing Religious Harmony through Rhetoric: An Analysis of Vivekananda's Selected Speeches
}

\author{
Surendra Prasad Ghimire \\ MPhil Scholar at Nepal Open University, Nepal \& Faculty of Hetauda School of \\ Management, Makwanpur, Nepal. \\ Mobile: +9779847197722 \\ surendra.ghimire7@gmail.com
}

\begin{abstract}
This research article reports how rhetorical elements used in the speeches of Swami Vivekananda at World Parliament of Religions supports to construct the religious harmony in the world. This study is based on qualitative interpretative research design and employs the theoretical ideas based on Richard Andrews to interpret the various rhetorical devices in his selected speeches. Furthermore, this paper analyzes the use of arguments in his speeches by using the idea developed by Stephen Toulmin and his visual rhetoric is analyzed using the idea based on Tracey Owens Patton. Findings show that use of rhetorical elements in his speeches contributes to make his arguments stronger to construct the religious harmony among the world religions despite the apparent contradiction among them. He incorporated rhetorical devices in his speeches such as metaphors, similes, parallelism, appropriate dictions and repetitions to persuade the
\end{abstract}


audience to establish his claim more effectively by making simple and understandable. His rhetoric of spiritualization of religions with the support of interpretation of Vedic philosophy contributes to integrate the world religions by stating that every human being has been created equally having the body and immortal spirit with them. His visual rhetoric including attractive bodily appearance, confidence and commanding voice helped him to attract the attention of the large mass of audience towards him. Findings of this article contribute to a better understanding that appropriate use of rhetorical elements supports to make effective communication and helps to persuade the audience to achieve the goal.

Key words: ethos, rhetorical devices, visual rhetoric, argument, spiritualism

\section{Introduction}

Swami Vivekananda addressed World Parliament of Religions at Chicago, Unite States of America which was organized by World- Columbian Exposition on the occasion of four hundredth anniversary of discovery of America by Christopher Columbus (Cleary, 1970). It was inaugurated on the $15^{\text {th }}$ May 1893 and its final session was ended on the $28^{\text {th }}$ October 1893 having discussion with the great issues of its contemporary period particularly about the world religions (Bonney, 1895). He participated in the different session of assembly at World Parliament of Religions in various time from 15th September 1893 up to 27th September 1893 such as 'Welcome' on 11th September, 'Why We Disagree ?' on $13^{\text {th }}$ September, 'Hinduism 'on $19^{\text {th }}$ September, 'Religion Not the Crying Need of India' on $20^{\text {th }}$ September, 'Buddhism the Fulfillment of Hinduism' on 26th September and his final speech on $27^{\text {th }}$ September (Manoj Phuwala, 1893). He delivered his speeches at World Parliament of Religions in front of thousands of audience including great philosophers, scholars and authors of his time who were there representing different sectors and religions from all over the world. Among them, his presentation of the paper on Hinduism was 
outstanding to establish the Hindu religious philosophy in the west (Vivekananda, 1893). He introduced Hinduism in the West and at the same time attempted to establish religious harmony by reflecting the common purpose of all religions of the world to lead the same goal (Poemusic, 1893). He showed great respect to all the religions of the world and at the same time he presented logically eastern religious philosophy in the parliament using the especial technique of rhetorical devices to make his arguments stronger to persuade the people.

Swami Vivekananda was well-informed regarding the issues of economic, social, political condition of the world. He was worried about the poverty and starvation of India and at the same time he found material prosperity in the west particularly in the United States of America with the support of science and technology (Chauhan \& Vivekananda, 2012). He attempted to maintain the balance between material prosperity and spirituality to make the blissful life by spreading the Vedic philosophy all over the world. He wanted to change the western perspectives towards the east and Hindu religion by modernizing it and at the same time he would like to bring social, cultural and political transformation in India by maintaining the harmonious relationship between the west and the east (Paranjape, 2013). He was religious leader and social reformer who wished to bring changes in India by combining the religion with social practical life (Kumar, 2017). He explained ancient Vedic philosophy in the new perspective for the betterment of the world and through which he would like to maintain the peace, prosperity and harmonious relationship among all the world religions. The basic concept of Neo Vedanta philosophy was started by his teacher Shree Ramakrishna and later on it was developed and spread by Swami Vivekananda making it understandable and practical in the modern life (Sooklal, 1993). In this context, this paper explores the rhetorical elements used in his speeches at World Parliament of Religions and at the same time analyzes how these rhetorical elements contributed to construct the religious harmony in the world. 


\section{Perception of Spiritualism}

Some of the previous and recent studies reported that the speeches of Swami Vivekananda at World Parliament of Religions reflected the themes related with spiritualism. $\mathrm{He}$ emphasizes over spiritualism which can be the best means to bring world religions together and it can also contribute to maintain the harmonious relationship between the west and the east. For examples, in his study Swami (2018) argued that Swami Vivekananda did not valorize any religion and philosophy over others rather he focused on the spiritualism by highlighting on the realization of divinity within oneself. Moreover, in the previous research Gordon (2014)_reported that Swami Vivekananda wanted to establish superiority of spiritualism in the world by analyzing the Vedic philosophy from the new perceptive. His new way of interpretation of Vedic philosophy helped him to promote spiritualism in the west. Furthermore, in recent study of Sachindra (2021) reflected that Swami Vivekananda attempted to maintain the balance between material development and spiritualism by spreading the importance of spiritualism in the west. This indicated that he would like to bridge the gulf between Indian spiritualism and western material prosperity. Likewise, Das (2021) reported that addressed of Swami Vivekananda at World Parliament of Religions appeals the west to maintain the balance between material prosperity and spirituality to make the life happier and successful. This indicated that he realized the urgency of balanced lifestyle providing equal focus on spiritual and material aspects to achieve the prosperity in the life. Furthermore, in the previous study Adiswarananda (2006) reported that Swami Vivekananda would like to establish unity between the west and the east by highlighting the importance of Vedanta philosophy of spiritualism. It reflected that he realized material prosperity as the primary requirement to understand the Vedic philosophy of spiritualism. Moreover, in recent study Maulana et al. (2020) reported that Swami Vivekananda contributed to bring modern thought by integrating the spiritualism with the western civilization. It indicated that he had broad vision regarding the religion and civilization of the world. Likewise, in recent study Poddar (2020) reported that Swami Vivekananda showed spiritualism as the highest form of knowledge and at the same time he stated that to have the knowledge of spiritualism one needs to have the knowledge of 
science and secularism. This indicated that Swami Vivekananda would like to maintain the balance between west and the east by focusing the importance of science and technology.

\section{Perception of Religion}

Some of the studies reported that Swami Vivekananda emphasized on Hindu religion by reinterpreting the Vedic philosophy of spiritualism from the new perspective. He would like to establish the link between the religion and the humanity by eliminating misconception regarding the world religions. He showed great respect to all the religions of the world. For example Kittelstrom (2009) reported that Swami Vivekananda was on the mission that he would like to purify and modernize Hinduism to establish it as global religion with the support of unity and brotherhood among the various religious people in the world. It indicated that he would like to solve the misunderstanding among the world religions with the help of unity and brotherhood. Likewise, Van Niekerk (2020) showed that Swami Vivekananda wanted to bring reformation and revival in Hinduism by creating the images of universalism. It showed that he would like to make Hinduism as world religion. In previous study Neufeldt (1993) argued that Swami Vivekananda was progressive in his time by eliminating dogmatisms on people and societies about religions and attempted to establish Hinduism as superior religion in the world. It indicated that he would like to break the narrow walls in the name of religion in the world. In the same way, Izah (2019) reported that Swami Vivekananda established the connection of Hinduism with the modern western thought by collaborating with reformers of Hinduism with the purpose of making Hinduism as universal religion. This reflected that he modernized Hindu religion by connecting it with modern western values. Similarly, in the recent article Rinehart (2020) indicated that Swami Vivekananda merged the classical Vedanta philosophy with the social program to establish the Hinduism as the religion for all the people of the world. He made Hinduism as the practical religion to solve the problem related to humanity. Furthermore, in previous study Prabhakar (2017) showed that Swami Vivekananda was humanist by keeping the human at the center. He considered every human as the God. Moreover, Naicker (2016) reported that Swami Vivekananda believed every human being would have potential to convert into divinity which is known as Buddha. These studies 
showed that Swami Vivekananda would like to establish Hindu religion as the world religion by modernizing and linking with humanity.

However, some of the studies reported that speech of Swami Vivekananda at World Parliament of Religions brought some overarching issues such as binary opposition and cultural confrontation between the west and the east. For instances, Roy and Hammers (2014) reflected that Swami Vivekananda's speech created the gap between the west and the east by showing spiritual superiority of the east and material greatness of the west. This dichotomy between the east and the west might create the problem instead of establishing the harmony. Moreover, in the previous study Brown (1999) showed that World Parliament of Religions exposed the cultural confrontation particularly between the western missionaries and Indian delegate Swami Vivekananda where both of them shared their own religious philosophy to establish their superiority and dominance in the world. It showed that Swami Vivekananda would like to valorize Hindu supremacy over others in the world. Furthermore, Bandyopadhyay and Mahapatra (2012) reported that Swami Vivekananda showed India has not been the country of ignorant but the place of profound knowledge with its glorious pasts. It showed that he would like to correct the western misunderstanding over India by showing the reality over them. Likewise, previous study of Sil (1995) showed that Swami Vivekananda was a visionary and a dreamer whose mission to the west was to make India socially progressive, politically stable and economically developed. It reflected that he had national interest rather than establishing harmonious world. Moreover, Medhananda (2020) argued that Swami Vivekananda was nationalist who attempted to spread Vedic philosophy of India as the foundation for the philosophy of spiritualism all over the world. It showed that he had the interest to establish Hindu dominance in the world with the support of philosophy of spiritualism. Likewise, in the previous study Neely (1994) reflected that World Parliament of Religions of 1893 provided the chance for the eastern religious philosophy to enter and flourish in the west despite the fact that many leaders of parliament believed supremacy of Christianity in the world. These studies indicated that Swami Vivekananda would like to strongly present Hindu religious philosophy in the west having the interest of establishing dominance of Hinduism all over the world. 


\section{Rhetorical Style}

Some of the studies showed that Swami Vivekananda had the unique art of using pluralistic rhetorical style in his speeches. For instance, in his study Stroud (2018) claimed that Swami Vivekananda effectively used pluralistic rhetorical style to promote Hindu philosophical tradition in the west. This reflected that he had the skills of using rhetorical elements to persuade the audience. Similarly, in his recent study, Tiwari (2020) showed that the speech of Swami Vivekananda at World Parliament of Religions moved the audience towards experiencing the sublimity by using effective rhetorical devices. With the support of effective use of rhetorical elements Swami Vivekananda established the notion of religious pluralism in the world. Likewise in the previous study Mitra (2018) argued that Swami Vivekananda's speech at World Parliament of Religions introduced Hinduism in the west with the support of religious pluralism. This reflected that he had the respect to all the world religions by having faith on pluralism. Moreover recent study of, Bhatti (2020) revealed that Swami Vivekananda strongly established his arguments at World Parliament of Religions with the support of effective communicative skills. He had unique art of using language. Furthermore, Arora (2016) argued that visibility of Swami Vivekananda such as his attractive dark body, cloth and his sweet melodious voice impressed particularly female audience during time of his speech. This reflected that visual rhetoric of Swami Vivekananda equally helped him to establish his arguments more strongly by attracting the attention of audience towards him.

Above literature of the speeches delivered by Swami Vivekananda at World Parliament of Religions disclosed various findings including spirituality, nationalism, religions, Hindu supremacy in the world. He advocated the notion of religious pluralism by using the pluralistic rhetoric strategies in his speech to provide equal values to all the world religions. He raised some overarching issues such as binary opposition between the west and the east in term of philosophy, science and technology. He criticized western materialistic ways of life and focused on maintaining the balance between spiritualism and material prosperity of the human beings. With the support of his effective art of communication he attempted to show how Hinduism as the religion of tolerance and universal brotherhood. It has been 
shown that the speech of Swami Vivekananda at world Parliament of Religions as the turning point in the history of world religion because of his innovative philosophical insight to construct the integration among the world religions despite the apparent contradictions. $\mathrm{He}$ has been shown as humanist, spiritual leader, reformer, and a dreamer who would like to establish harmonious world without valorizing any religion and philosophy over others. Researchers found his speech fertile source to study from different perspectives to explore the relation between west and the east. He analyzed and established the eastern Vedic philosophy strongly in the west. He highlighted the Vedic concept of spiritualism as the essence of all the religions of the world. He introduced spiritualism in the west as the binding force to all the world religions. He stated that the purpose of all the religions of the world has been similar that they lead all their followers towards the God. He has taken all the religions of the world as the paths to lead the believers to the God.

However, there have been limited literatures about how rhetorical devices used in the speeches of Swami Vivekananda at World Parliament of Religions. I found that he used many rhetorical devices and argumentation in his speeches at World Parliament of Religions to persuade and influence the audience most powerfully to fulfill his purposed goal. His visual rhetoric has made his speeches quite unique and became the effective means to attract the attention of the audience. Therefore, here, in this study I want to focus how his rhetorical strategies that he used in his speeches support to persuade the audience and establish his idea strongly to meet his goal. He expressed his idea using the special rhetorical devices and arguments. In this context, I want to study the role of rhetorical devices to construct the intended meaning of the speaker. Therefore, this study analyzes how the rhetorical devices used in the speeches delivered by Swami Vivekananda at World Parliament of Religions in 1893 support to construct the religious harmony in the world. This study employs qualitative interpretative research design based on the idea given by Cohen et al. (2018). In the same way, procedure of interpretation such as analyzing, discussion of findings with other literature, personal view on overall findings are based on the methods written by Creswell and Creswell (2018). Furthermore, this study examines the elements of arguments of the speech delivered by Swami Vivekananda with the theoretical lens discussed by Toulmin et al. (1984). Moreover, this article analyzes the rhetorical 
devices and rhetorical move of his speech particularly by using the ides developed byAndrews (2013). Furthermore, this paper evaluates the visual rhetoric of Swami Vivekananda including gestures, his appearance, and various images that he created during the speech with the support of theory developed by Patton (2020). Moreover, rhetorical devices of his speeches of World Parliament of Religions have been analyzed and evaluated with the support of theoretical lens and insights provided by Aristotle (Cope, 1867). Reading of various archive documents provides the skills and ideas of analyzing the rhetorical aspect of his speeches. Observation of his audio and video speeches supports to derive various qualitative data regarding his uses of rhetorical devices and it further contributes to analyze his visual rhetoric. Finally, his whole speeches have been interpreted with the support of above theoretical lens to find out how elements of arguments, rhetorical devices, and visual rhetoric of Swami Vivekananda support to construct the religious harmony in the world. These theoretical insights also support to find out how effective use of rhetorical devices contributes to persuade the audience to achieve the goal.

\section{Rhetoric and Religious Harmony}

Swami Vivekananda addressed the assembly of World Parliament of Religions on various occasion. He responded to his welcome on11th September 1893 and he stated that all the religions of the world have equally important values because they lead the followers towards the unification with the God. He defined the Vedic philosophy in the simple way with the support of various rhetorical devices. Similarly, on $13^{\text {th }}$ September 1893 , he spoke on 'Why We Disagree?' by providing the profound example from the story of the frog to reflect how religions of the world limit the followers by constructing the narrow boundaries. Furthermore, he presented the paper on 'Hinduism 'on $19^{\text {th }}$ September and very strongly established his idea of Hinduism in the west. He showed that how the concept of spiritualism of the Vedic philosophy could be the best means to break the narrow and limited walls created by the world religions. Moreover, he introduced the Veda as the accumulated store of spiritual law discovered by various Rishis in the various times. $\mathrm{He}$ focused on humanity, harmony, and prosperity of the world by maintaining the balance between material and spiritual life. Similarly, he added his notion of religion on 'Religion 
Not the Crying Need of India 'on $20^{\text {th }}$ September 1893. He highlighted the importance of cooperation to establish the harmonious relation among the world humanities. He criticized to Christians that they did nothing to protect the people from starvation in India. He emphasized that religion and spiritualism could be taught only after solving the problem of basic needs of human being. Likewise, he spoke on 'Buddhism the Fulfillment of Hinduism' on 26th September1893. He argued that Buddhism has been the part of Hinduism. Finally, he addressed the assembly on $27^{\text {th }}$ September. He showed his desire and purpose to establish the harmony among the religions of world.

Swami Vivekananda claimed religious harmony with enough grounds stating that all the religions in the world have been similar in the sense that their basic purpose has been the same to lead the followers towards the unification with the God. Grounds of his argument have added genuine support for his claim. His claim has been backed by the various human religious principles, norms and values. Warrants of his arguments exhibited authentic and reliable grounds of his claim. Furthermore, he attempted to avoid the controversies among the world religions by using the rhetoric of spiritualism and developing mutual understanding among all the religions. In doing so, he set the common ground among the world religions. He used various rhetorical devices such as smiles, metaphors, appropriate dictions, parallelism, and repetitions, to persuade and influence the audience to establish his claim more effectively by making simple and understandable. The visual rhetoric of Swami Vivekananda during the time of speech at World Parliament of Religions supported him to attract the attention of audience towards the subject matter. His visibility such as dress up, his dark skin, large eyes, made him outstanding in front of the audience. His verbal rhetoric has become more effective due to his ability of using powerful visual images in his speech particularly from the Vedas. His confidence and commanding English language assisted him to clarify even complex arguments in the simple and easy way. Furthermore, He foregrounded his language in his speeches by breaking the traditional way of addressing to the people. He said that "Sisters and Brothers of America" instead of Mr., Ms. or ladies and gentlemen. His rhetorical strategy of defamiliarization of his language as discussed by Shklovsky (1917) contributed to make his language poetic. Moreover, such rhetoric of respect also contributes to develop the harmonious relationship of brotherhood and 
sisterhood with all the religious people. Similarly, he used another rhetorical strategy of parallelism in his speech to highlight his claim. For example in his response to welcome he said that:

I thank you in the name of the most ancient order of monks in the world; I thank you in the name of mother of religions; and I thank you in the name of millions and millions of Hindu people of all classes and sects [...] I am proud to belong to a religion which has taught the world both tolerance and universal acceptance. We believe not only in universal toleration, but we accept all religions as true.

Above remarks reflected that Swami Vivekananda used special rhetorical device of parallelism which supported him to provide focus on the idea and at the same time it made his speech rhythmical to attract the attention towards him. His metaphorical expression of "Mother of Religions" indicates the source of unity, harmony and creation of the world. These ideas are in some extent reflected in the recent study of Tiwari (2020) which showed Swami Vivekananda's power of using rhetorical devices moved the audience towards experiencing the sublimity. Moreover, these remarks helped to prove the credibility and authenticity of Swami Vivekananda by highlighting his glorious ancient religion of Hinduism which has the features of universalism and tolerance. Such language of Swami Vivekananda facilitates to create ethos towards him. Furthermore, his rhetoric of respect to all the religions of world shows his technique of creating the binding force to unite them. Similarly, he used another rhetorical strategy of telling the story which was developed in ancient Greece to simplify the complex idea. He said that:

"Where are you from?" "I am from the sea." "The sea! How big is that? Is it as big as my well?" and he took a leap from one side of the well to the other. "My friend," said the frog of the sea, "how do you compare the sea with your little well?" Then the frog took another leap and asked, "Is your sea so big?" "What nonsense you speak, to compare the sea with your well!" "Well, then," said the frog of the well, "nothing can be bigger than my well; there can be nothing bigger than this; this fellow is a liar, so turn him out." 
Swami Vivekananda used the rhetorical strategy of telling the story to develop his arguments to show how religions make the human limited by showing the incomplete reality rejecting all outside of them. This argument is in some extent paralleled with the previous study of Neufeldt (1993) which showed Swami Vivekananda was progressive in his time by eliminating dogmatisms about religions in the society. His power of reflecting even complex idea in a simple way using the rhetorical devices contributed to achieve his goal of creating the religious harmony in the world. It has been taken as effective rhetorical means to establish the idea effectively with enough fun. In the same way, his confidence in his speeches and his art of appropriate selection of words contribute to establish his claim effectively. Moreover, his dialogic way of presentation in the story showed that his ability to provide respect to all the voices. He further said that:

I am Hindu. I am sitting in my own little well and thinking that the whole world is my little well. The Christian sits in his little well and thinks the whole world is his well. The Mohammedan sits in his little well and thinks that is the whole world.

Above passage showed the shortcoming of religions with the special rhetorical strategy of metaphor of "Well". Here, he directly compared the religions of the world with the small well to show the reality of the religions that they divided the people in different groups with various worldviews. Therefore, he developed his arguments to establish religious harmony by spiritualizing the religions. He stated his claim that every human being has been a spirit including all the people belong into different religions of the world. He sets strong ground by interpreting the Veda from the new perspectives. He analyzed the Vedic philosophy as foundation of modern sciences and spirituality. By showing the connection of Vedic philosophy as underpinning of modern science, technology and spirituality empowered the ground of his claim. Totality of religious principles and rules strongly backed his claim of religious harmony in the world. This idea is at some level resonated with the study of Medhananda (2020) which argued that Swami Vivekananda attempted to spread Vedic philosophy of India as the foundation for the philosophy of spiritualism all over the world. He introduced the Vedic philosophy systematically to show how spirituality is the divine power. He stated that: 
The Vedas teach that the soul is divine, only held in the bondage of matter; perfection to be reached when this bond will burst, and the word they use for it is therefore, Mukti-- freedom, freedom from the bonds of imperfection, freedom from death and misery.

These remarks further implied that Vedic philosophy of divine soul has perfect and universal to establish harmonious relationship with everything. When this divine soul disconnected its relation with matter only gets emancipated and forgets any kind of divisive factors around the world including death and misery. Therefore, soul has been considered as God. He further developed his argument by stating that "The Vedas teach us that creation is without beginning or end. Science is said to have proved that sum total of cosmic energy is always the same." Vedic philosophy indicated that the creation of the world has been going on without beginning and end with the support of cosmic energy. This has been proved by the modern science and technology stating that the totality of energy has not been finished. It could only change the form. Therefore, Vedanta philosophy has been a practical and scientific method to understand the fundamental principles of spirituality and humanity of the world. His rhetorical strategy of proving the Vedic philosophy by modern science validates the ground for his claim. This further supported to make his argument more inclusive by incorporating the role of materiality to realize the spirituality with in them. This argument is at some level resonated with the recent study of Poddar (2020) that reflected spiritualism has been the highest form of knowledge which cannot be acquired without the knowledge of science and secularism. Swami Vivekananda further said that:

I am a spirit living in a body. I am not body. The body will die, but I shall not die. Here am I in this body, it will fall, but shall go on living. I had also a past. The soul was not created, for creation means a combination which means a certain future dissolution. If then the soul was created, it must die.

His rhetoric of expressing idea with providing example of his own really impressed the audience and in doing so, contributed to strengthen the reliability and acceptability of his claim that human being has not been only the body but the spirit. He separated the body and the spirit to make his arguments stronger to show how spirit is immortal and has 
universal existence. His argument is that sprit has not been created therefore it has not been died like created body. His rhetoric of creating immortal spirit set the foundation for integrating of all the human being belonging in various religions of the world. The notion of spirituality has become the inclusive means to unite all the people belonging into various religions of the world. He further said that:

Hindu believes that he is a spirit. [...] sword cannot piece-him, the fire cannot burn-him, the water cannot melt -him, the air cannot dry. The Hindu believes that every soul is a circle whose circumference is nowhere, but whose center is located in the body and that death means the change of this center from body to body. Not is the soul bound by the conditions of matter. In its very essence it is free, unbounded, holy, pure, and perfect.

These remarks reflected how Swami Vivekananda developed his argument by showing the concept of immortality of the spirit in contrast to the body. He showed that reality has been the spirit that has been immortal. The spirit has been evolving on the basis of the deeds that it had been involved in the previous life. So concept of death has been associated with the migration of soul from one body to another body. It has been endless process. Here, his intended claim is that soul or what we called spirit has been considered as God. Therefore, his argument and rhetorical strategy exhibited the equality among all the people that they have been created equally having the body and immortal soul with them. To support his claim, he further stated that:

And what is His nature? He is everywhere, the pure and formless One, the Almighty and the All-merciful. "Thou art our father, Thou art our mother, Thou art our beloved friend, Thou art the source of all strength; give us strength. Thou art He that beareth the burdens of the universe; help me bear the little burden of this life." Thus sang the Rishis of the Vedas. And how to worship Him? Through love. "He is to be worshipped as the one beloved, dearer than everything in this and the next life."

His remarks indicated that human soul is God and that is universal, formless. It has been the source of love and perfection. It has not exposed any discrimination on the basis of 
religions color and anything like that. It creates the perfect harmony in the world with the support of love for everyone. This idea is at some level paralleled with the study of Kittelstrom (2009) which showed that Swami Vivekananda would like to establish brotherhood among the various religious people in the world by modernizing Hinduism. Furthermore, he sang the above song in his speech which further supported to establish his claim strongly by moving the audience with the art of his expression. The repetition of the term "Thou" also reflected the power of spirit as equal to God in the world. He generalized the concept of immortality of the spirit to all the human belonging to all the religions of the world. He further said:

And so when a soul becomes perfect and absolute, itmust become one with Brahman, and it would only realize the Lord as the perfection, the reality, of its own nature and existence, the existence absolute, knowledge absolute, and bliss absolute. We have often and often read this called the losing of individuality and becoming a stock or a stone.

These remarks showed that everybody is the God having the immortal spirit that has become prefect after the union with the Brahman. The ultimate reality of life is Brahman which is formless and beyond the physical reality. Everything expects Brahman is illusion. It has been the stage of perfection and harmony with everything in the world. This idea is at some level resonated with the study of Naicker (2016) which reported that Swami Vivekananda believed every human being would have potential to convert into divinity. As he further said "Man is to become divine by realizing the divine". Therefore, he considered the conflict among the religions as delusion which has not directed towards the perfection. He further said:

...a universal religion, it must be one which will have no location in place or time; which will be infinite like the God it will preach, and whose sun will shine upon the followers of Krishna and of Christ, on saints and sinners alike; which will not be Brahminic or Buddhistic, Christian or Mohammedan, but the sum total of all these, and still have infinite space for development $[\ldots]$ it will be a religion which will have no place for persecution or intolerance. 
Therefore, he came to the conclusion that all the religions of world have been the similar. Hence the purpose of every religion has to create the union with the God. So that fundamental principle and the purpose of all the religions of the world are the similar that they create the union between soul and the God. There has not been any kind of disparity in the name of religions and all religious people can be adjusted together. Therefore, there has not been the question of superiority and inferiority of the religions since they have the similar purpose. This type of idea of religion is at some level resonated with the study of Swami (2018) which showed that Swami Vivekananda focused on spiritualism and humanism without valorizing any religion and philosophy over other. He showed that all the religions are the paths to reach up to the God. He further said:

To the Hindu, then, the whole world of religions is only a travelling, a coming up, of different men and women, through various conditions and circumstances, to the same goal. Every religion is only evolving a God out of the material man, and the same God is the inspirer of all of them. Why, then, are there so many contradictions? They are only apparent, says the Hindu.

Above remarks implied that ultimate aim of all religions of the world has been the same of uniting the human with the God. Here, so called debate of superiority of religions has been considered as illusion and it indicated the lack of proper understanding about the nature of religions. This notion of harmony among the world religions is at some level paralleled with the study of Zaheer (2016) which showed Swami Vivekananda provided equal respect to all the religions of the world. The main purpose of the religions has to establish perfect and blissful life by uniting individual and the God which has not been possible without the perfect harmony between individual soul and supreme universal soul. As Swami Vivekananda stated "to gain this infinite universal individuality, this miserable little prisonindividuality must go". This reflected that all the people of the world belonging in the various religions should come out of narrow box of individualism and should join with the universal individuality which provides integration among all the world religions. $\mathrm{He}$ corrected the misconception regarding the world religions which terminated the religious conflict and set the common foundation by reinterpreting ancient Vedic philosophy of spiritualism in the simple and argumentative way with the support of various rhetorical 
elements. The effective use of rhetorical elements and argumentation support him to persuade the audience to establish religious harmony in the world by eliminating the apparent contradiction among the world religions.

\section{Conclusion}

Analysis of this article has identified that Swami Vivekananda's art of using rhetorical devices supported him to establish religious harmony among the world religions. He developed his claim of religious harmony with sufficient ground and his claim has been backed by the various human religious principles, norms and values. Warrants of his arguments showed reliable and acceptable ground of his claim. He argued with sufficient evidences that each individual has been the soul which is immortal and always evolving on the basis of the activities that a person involved during living period. Same notion of spiritual being has been generalized to draw the conclusion that all the religions of the world have been similar due to their common goal of the unification with the God. He used special rhetorical devices including smile, metaphor, images, repetition, and parallelism, to make his speech effective and powerful to support his claim. He developed his arguments with the support of rhetorical strategy by analyzing Vedic philosophy as foundation of modern science and spirituality. His rhetoric of spiritualizing the religions helped to construct the common purpose of world religions of unification of their soul with God which supported to end the controversies of the religions. His visual rhetoric including attractive bodily appearance, confidence and commanding voice helped him to attract the attention of the large mass of audience towards him. His rhetorical strategy of defamiliarization of his language by selecting unique diction helped him to make his speech poetical. His rhetorical technique of defining the Hindu religion as the mother of all religions with the support of Vedic philosophy of spiritualism and showing his glorious position as being a Hindu reflected his authenticity and reliability to deliver the speech. Similarly his rhetoric of respect to other religions as the way to reach to the God paved the way towards creating the harmony in the world religions. Furthermore, his rhetorical strategy of telling the story and singing the song contributed to conceptualize the complex ideas easily to the common people. He further developed his argument that human soul has 
been God that has been formless pure and universal. It has not done any kind of discrimination on the basis of religions, color and anything like that. Finally, he reached into the conclusion that the soul creates the perfect harmony in the world with the support of love for everyone. The creation of world has been going on without beginning and end with the support of cosmic energy that formed as the union of individual and universal soul as stated by Vedic philosophy. Findings of this article help to a better understanding that appropriate use of rhetorical elements reinforce to make effective communication and to persuade the audience to achieve the goal.

\section{References}

Adiswarananda, S. (2006). Vivekananda, world teacher: his teachings on the spiritual unity of humankind. SkyLight Paths Publishing.

Andrews, R. (2013). A theory of contemporary rhetoric. Routledge.

Arora, A. (2016). A black pagan in orange clothes": Swami Vivekananda's American travels. Literature Interpretation Theory, 27(1), 71-89. https://doi.org/.org/10.1080/10436928.2015.1132531

Bandyopadhyay, R., \& Mahapatra, R. L. (2012). Redefining Swami Vivekananda as a Post Colonial Thinker: Impacts on Education System.

Bhatti, B. (2020). Decoding the Language of Religious Discourse: A Linguistic and Communicative Analysis of Swami Vivekananda's 'Chicago Address' at World's Parliament of Religions. Dialog.

Bonney, C. C. (1895). The World's Parliament of Religions. The Monist, 321-344.

Brown, L. K. (1999). Mission, a cultural confrontation. Journal of Dharma, 24(4), 378-401.

Chauhan, A. S., \& Vivekananda, S. (2012). Select speeches. Barcilly, PBD.

Cleary, J. F. (1970). Catholic Participation in the World's Parliament of Religions, Chicago, 1893. The Catholic Historical Review, 55(4), 585-609.

Cohen, L., Manion, L., \& Morrison, K. (2018). Research Methods in Education (8th ed.). Routledge.

Cope, E. M. (1867). An Introduction to Aristotle's Rhetoric: With Analysis, Notes and Appendices. Macmillan.

Creswell, J. W., \& Creswell, J. D. (2018). Research Design: Qualitative, Quantitative, and Mixed Methods Approaches (5th ed.). Sage. https://lccn.loc.gov/2017044644

Das, D. (2021). Relevance of Swami Vivekanand's concept of national building. 
Gordon, D. B. (2014). on what East offers West. Education About ASIA, 19(3).

Izah, S. A. (2019). Swami Vivekananda's perspective of radical universalism in Hinduism UNIDA].

Kittelstrom, A. (2009). The international social turn: unity and brotherhood at the World's Parliament of Religions, Chicago, 1893. Religion American Culture, 19(2), 243274.

Kumar, S. (2017). Swami Vivekananda: As a social reformer, . International Journal of Multidisciplinary Educational Research, 6(7), 44.

Manoj Phuwala. (1893). Chicago Speech of Swami Vivekananda at the World Parliament of Religions for ${ }_{\mid} R S M \mid S R M$ https://www.youtube.com/watch? $\mathrm{v}=\mathrm{ii} 7 \mathrm{obeNa} 20 \mathrm{~g}$

Maulana, A. M., Sufratman, S., \& Izah, S. A. (2020). Spirit of Vedanta ushering Hinduism to the idea of universalism (Discourse on Swami Vivekananda's thought). Journal of Comparative Study of Religions, 1(1). https://doi.org/org/10.2111/jcsr.v1i1.4978

Medhananda, S. (2020). Was Swami Vivekananda a Hindu Supremacist? Revisiting a longstanding debate. Religions, 11(7), 368. https://doi.org/org/10.3390/rel11070368

Mitra, A. (2018). The dawn of religious pluralism: The importance of the 1983 World Parliament of Religions in Chicago. Prabuddha Bharata.

Naicker, S. (2016). Analysis of water-related metaphors within the theme of religious harmony in Swami Vivekananda's Complete Works. Theological Studies, 72(4), $1-8$.

Neely, A. (1994). The Parliaments of the World's Religions: 1893 and 1993. International Bulletin of Missionary Research, 18(2), 60-64. https://doi.org/org/10.1177\%2F239693939401800205

Neufeldt, R. (1993). Reflections on Swami Vivekananda's Speeches At the World Parliament of Religions, 1893. Journal of Hindu-Christian Studies, 6(1), 4.

Paranjape, M. R. (2013). Representing Swami Vivekananda. In Making India: Colonialism, National Culture, and the Afterlife of Indian English Authority (pp. 129-162). Springer.

Patton, T. O. (2020). Visual Rhetoric: Theory, Method, and Application in the Modern World. In Handbook of Visual Communication (pp. 125-138). Routledge.

Poddar, A. (2020). A study of efficacy of secularism and Swami Vivekananda. Jorunal of Critical Review.

Poemusic, A. (1893). Original voice of Swami Vivekananda / Speech at Chicago 1893/ Parliament of The World's Religions. https://www.youtube.com/watch?v=QIyxnm4-d8k 
Prabhakar, M. (2017). Swami Vivekananda's Spiritual Universalism. Asia Pacific Journal of Research, 1(21), 44-50.

Rinehart, R. (2020). Swami Vivekananda. In The Routledge Handbook of Hindu-Christian Relations (pp. 307-315). Routledge.

Roy, A., \& Hammers, M. L. (2014). Swami Vivekananda's rhetoric of spiritual masculinity: transforming effeminate Bengalis into virile men. Western Journal of Communication, $78(4)$ $545-562$. https://doi.org/org/10.1080/10570314.2014.914567

Sachindra, S. (2021). Swami Vivekananda's Vision on The Social-Religious Aspect of Bharat: An Analysis. Jahnavi Sanskrit E-Journa.

Shklovsky, V. (1917). Art as technique. Literary Theory: An Anthology, 3.

Sil, N. P. (1995). Swami Vivekananda in the west: The legend reinterpreted. South Asia: Journal of South Asian Studies, 18(1), 1-53. https://doi.org/org/10.1080/00856409508723227

Sooklal, A. (1993). The Neo-Vedanta Philosophy of Swami Vivekananda. Nidan: International Journal for Indian Studies, 1993(5), 33-50.

Stroud, S. R. (2018). The pluralistic style and the demands of intercultural rhetoric: Swami Vivekananda at the World's Parliament of Religions. Advances in the History of Rhetoric, 21(3), 247-270. https://doi.org/org/10.1080/15362426.2018.1526545

Swami, N. (2018). Swami Vivekananda and the World's Parliament of Religions 1893 new $\begin{array}{llll}\text { perspectives. Prabuddha Bharata, } 123(9 & 10), & \text { 653-712. }\end{array}$ https://doi.org/https://hcommons.org/deposits/item/hc:22855

Tiwari, J. S. (2020). Theme of Swami Vivekananda's Speeches in the light of Longinus' essay 'On the Sublimity'.

Toulmin, S. E., Rieke, R. D., \& Janik, A. (1984). An introduction to reasoning.

Van Niekerk, B. (2020). Swami Vivekananda: Revival and reform in the making of Hinduism. Theological Studies, 76, 1-8. https://doi.org/org/10.4102/hts.v76i4.6110

Vivekananda, S. (1893). Paper on Hinduism. InThe Complete Works of Swami Vivekananda, 1 .

Zaheer, N. (2016). Reinvestigating Vivekananda's image as a religious pluralist and universalist. The Islamic Culture" As-Saqafat-ul Islamia" الثقافة الإسلامية-Research Journal-Sheikh Zayed Islamic Centre, University of Karachi(36), 7-25. 